\title{
Yabancı Dil Olarak Türkçe Öğretimi Ders Kitaplarında Dinleme Becerisi Alanında Kullanılan Alıştırmaların Değerlendirilmesi*
}

\author{
Dr. Bayram Özbal \\ Millı̂ Ĕ̆itim Bakanlı̆̆̆ \\ ozbalbayram@hotmail.com
}

\author{
Prof. Dr. Ayten Genç \\ Hacettepe Üniversitesi, Eğitim Fakültesi \\ Alman Dili Ĕ̆itimi Ana Bilim Dalı \\ dogu@hacettepe.edu.tr
}

Öz

Yabancı dil öğretimi ders kitaplarında beceri alanlarına göre belirlenen hedef davranışlar, alıştırmalar yoluyla öğrencilere kazandırılmaya çalışılır. Öğrencilere beceri alanlarında belirlenen hedef davranışları da kazandırmanın yolu da farklı türde ve yeterli miktarda alıştırma yapmaya dayanır. Bu nedenle ders kitaplarında kullanılan alıştırmaların temel ve alt beceriler açısından dengeli bir dağılım göstermesi kadar kullanılan alıştırma türlerinde de çeşitliliğin sağlanması önemlidir. Bu çalışmanın amacı da yabancı dil olarak Türkçe öğretiminde yaygın olarak kullanılan dört öğretim setinin temel seviye (A1-A2) ders kitaplarında dinleme becerisi alanında kullanılan alıştırmaların diğer beceri alanlarına göre oranlarını, kullanılan alıştırma türlerini ve kullanım sıklıklarını tespit etmektedir. "İstanbul Yabancılar İçin Türkçe", "Yedi İklim Türkçe", "Gazi Yabancılar İçin Türkçe" ve "Yeni Hitit Yabancılar İçin Türkçe" setlerinin temel seviye (A1-A2) ders kitaplarından doküman incelemesi yoluyla veriler toplanmış ve tümevarımsal içerik analiziyle değerlendirilmiştir. Çalışma sonuçları, incelenen yabancı dil olarak Türkçe temel seviye (A1-A2) ders kitaplarında dört temel dil becerisi arasında en az alıştırmaya dinleme becerisi alanında yer verildiğini ve dinleme-anlamaya yönelik alıştırma çeşitliliğinin artırılması gerektiğini göstermektedir.

Anahtar Kelimeler: Yabancı dil olarak Türkçe, ders kitapları, dinleme becerisi, alıştırmalar.

\section{Evaluation of Exercises Used in Listening Skill Area in Teaching Turkish as a Foreign Language Textbooks**}

\footnotetext{
Abstract

The target behaviors determined according to skill areas in foreign language teaching textbooks are to be transmitted to students through the exercises. The way target behaviors determined in the skill areas are transmitted to students is also based on doing an adequate number of various exercises. Therefore, it is important that the exercises used in the

* Bu makale, Prof. Dr. Ayten Genç danışmanlığında tamamlanan "Yabancı Dil Olarak Türkçe Ders Kitaplarında Alıştırmaların İncelenmesi: A1-A2 Düzeyi" başlıklı doktora tezinden üretilmiştir.

** This article is part of the PhD thesis titled "Investigation of Exercises in Turkish as a Foreign Language Textbooks: Level A1-A2", which was written by Bayram ÖZBAL under the supervision of Ayten GENÇ. 
textbooks show a balanced distribution in terms of basic and sub-skills as well as the diversity in the types of exercises used. The aim of this study is to determine the proportions of the exercises used in the listening skill relative to other skills, the types of exercises and the frequency of their use in the basic level (A1-A2) textbooks of the four teaching sets commonly used in teaching Turkish as a foreign language. Data were gathered through document analysis from the basic level (A1-A2) of the teaching sets of "Istanbul Turkish for Foreigners", "Yedi İklim Turkish", "Gazi Turkish for Foreigners", "Yeni Hitit Turkish for Foreigners" textbooks and evaluated by inductive content analysis. The results of the study indicate that the listening skill area included the least amount of exercises in the four skills and the diversity of listening-understanding exercises should be increased in the examined Turkish as foreign language (A1-A2) textbooks.

Keywords: Teaching Turkish as a foreign language, textbooks, listening skill, exercises. 


\section{Gİiș}

Yabancı dil olarak Türkçe öğretiminde temel amaç, öğrencilerin dört temel beceri alanında dil becerilerini geliştirmektir. Temel becerilerden biri olan dinleme becerisi anlamaya dayalı bir beceridir. Ur'a $(2012$, s. 102) göre dinleme öğretiminin temel amacı, öğrencilerin gerçek yaşamda karşılaşabilecekleri olası doğal dinleme ortamlarıyla başa çıabilme becerilerini geliştirmektir. Yabancı dilde etkili iletişim kurabilmek dinleyicinin konuşanın iletisini ne kadar anladığıyla yakından ilişkilidir. Bu nedenle dinleme becerisi özellikle etkilili iletişim becerisi için oldukça önemlidir.

Yabancı dil öğretiminde dinleme becerisi birçok araştırmacıya göre dört temel dil becerisi içinde en zor gelişenidir (Demirel, 2016, s. 98; Tüm, 2016, s. 127). Bu durumun temel nedenlerinden birisi dinleme becerisinin birçok süreç ve aşamayı içinde barındırması olarak gösterilebilir. Etkili ve verimli bir dinlemenin gerçekleşmesi için dinleme sürecinde farklı fiziksel, zihinsel ve psikolojik süreçler devreye girer. Bu süreçler, sesleri algılama-tanımadan iletiyi anlamaya-yorumlamaya kadar sıralanabilir. Bir diğer neden ise yabancı dil olarak Türkçe öğretiminde de dinleme becerisinin ihmal edilmesi ve öğretim setlerinde bu beceri alanına diğer beceriler kadar önem verilmemesi olarak gösterilebilir (Şimşek, 2016; Yavuz, 2016; Yılmaz ve Babacan, 2015, s. 291). Dinleme eğitiminde karşılaşılan bu güçlüklerin üstesinden gelmede ders kitapları önemli rol oynar. Çünkü ders kitaplarında öğretim programları doğrultusunda belirlenen hedeflere ulaşmak üzere beceri alanlarına göre yeterli alıştırmaya yer verilmesi gerekir. Alıştırmalar yoluyla da beceri alanlarına göre belirlenen hedef davranışlar öğrencilere kazandırılmaya çalışılır. Bu nedenle yabancı dil olarak Türkçe öğretimi için hazırlanan ders kitaplarında alıştırmaların temel ve alt beceri alanlarına göre dengeli şekilde hazırlanması önemlidir. Diğer bir önemli nokta da beceri alanlarına göre kullanılan alıştırma türlerinde çeşitliliğin ve niteliğin sağlanmasıdır. Ders kitaplarında farklı alıştırma türleri kullanılarak öğrenciler gerçek yaşamda karşılabilecekleri olası dinleme ortamlarına hazırlanır. Ayrıca alıştırmalar yoluyla dinleme eğitiminin amacına ulaşıp ulaşmadığı da değerlendirilebilir.

$\mathrm{Bu}$ çalışmanın temel amacı, yabancı dil olarak Türkçe öğretiminde kullanılan "İstanbul Yabancılar İçin Türkçe", "Yedi İklim Türkçe", "Gazi Yabancılar İçin Türkçe" ve "Yeni Hitit Yabancılar İçin Türkçe" setlerinin temel seviye (A1-A2) ders kitaplarının dinleme alıştırmaları açısından incelenmesidir.

\section{YÖNTEM}

Yabancı dil olarak Türkçe öğretimi ders kitaplarında dinleme bölümlerinin betimlenmesi ve detaylı olarak alan yazın desteğiyle incelenmesi amacıyla yapılan bu çalışma, kuramsal analitik araştırma olarak desenlenmiştir. Kuramsal analitik araştırma, mevcut durumun belirlenmesi ve analiz edilmesine yönelik bir araştırma desenidir. $\mathrm{Bu}$ nedenle araştırma nitel bir çalışmadır. Nitel araştırmalarda araştırmacı verileri düzenler, tasnif eder, sentezler, örüntüler çlkarır ve bu işlemler sonucunda kavramlara ulaşır ve bulguları raporlaştırır (Gürbüz ve Şahin, 2017, s. 431). Bu bağlamda yabancı dil olarak Türkçe öğretimi alanında kullanılan temel seviye (A1-A2) için hazırlanmış öğretim setleri nitel veri toplama yöntemlerinden doküman incelemesi yoluyla incelenmiştir. Doküman incelemesi, araştırılması hedeflenen olgu veya olgular hakkında bilgi içeren yazılı ve görsel

SEFAD, 2019; (42): 197-212 
materyallerin analizidir (Yıldırım ve Şimşek, 2016, s. 189). Bu nedenle doküman incelemesinin bu çalışmanın doğasına uygun veri toplama yöntemi olduğu söylenebilir.

\subsection{Veri Kaynakları}

Araştırmanın veri kaynaklarını yabancı dil olarak Türkçe öğretimi için temel seviyede (A1-A2) hazırlanmış aşağıda adları belirtilen ders kitapları oluşturmaktadır:

- İstanbul Yabancilar İçin Türkçe A1-A2 Ders Kitapları,

- Yedi İklim Türkçe A1-A2 Ders Kitapları,

- Gazi Yabancılar İçin Türkçe A1-A2 Ders Kitapları,

- Yeni Hitit Yabancılar İçin Türkçe A1-A2 Ders Kitabı.

\subsection{Verilerin Toplanması ve Analizi}

Bu çalışmada nitel veri analiz yöntemlerinden biri olan içerik analizi yaklaşımı esas alınmıştır. İçerik analizinde amaç, toplanan verileri açıklayabilecek kavramlara ve ilişkilere ulaşmak için derin bir işleme tabi tutmaktır. $\mathrm{Bu}$ amaçla toplanan veriler önce tanımlanır/kavramsallaştırılır daha sonra da birbirine benzeyen veriler belirli kavramlar ve temalar altında bir araya getirilerek yorumlanır (Yıldırım ve Şimşek, 2016, s. 242).

Çalışmada araştırmacı tarafından elde edilen verilerin doğrulanmasında bir uzman görüşüne başvurulmuştur. Elde edilen verilerin doğrulanmasında ve karşılaştırılmasında Miles ve Huberman (1994) tarafından geliştirilen aşağıdaki güvenilirlik formülü uygulanmıştır.

\section{Güvenirlik= Görüş Birliğii/Görüş Ayrıllğı+Görüş Ayrıllı̆g1X100}

Alan yazında yukarıda yer alan güvenirlik formülü ile elde edilen sonucun en az \%70 olması güvenirliğin sağlanabileceği anlamına gelmektedir (Miles ve Huberman 1994'ten akt. Cavkaytar, 2009). Çalışmanın güvenirliğinde tez danışmanı, alandan bir uzman ve araştırmacı yer almıştır ve güvenirlik hesaplaması yukarıdaki formüle göre \%95 olarak belirlenmiştir.

\section{BULGULAR VE YORUMLAR}

"İstanbul Yabancılar İçin Türkçe" setinin temel seviye ders kitaplarında dinleme alıştırmalarına "Dinleme" başlığı altında yer verilmiştir. Bu başlıklarda renkli şeritlerden yararlanılmıştır. Dinleme bölümlerine A1 düzeyindeki ders kitabının ilk ünitesinin birinci ve ikinci teması haricindeki tüm temalarda "Dil Bilgisi" bölümünden sonra yer verilerek standart sağlanmıştır. "Yedi İklim Türkçe" setinin temel seviye ders kitaplarında ise dinleme alıştırmalarının temalarda veriliş sırasında bir standart söz konusu değildir. Dinleme alıştırmalarına yönlendirici sembol yoluyla geçiş yapılmaktadır. "Gazi Yabancılar İçin Türkçe" setinin temel seviye ders kitaplarında, dinleme alıştırmalarına "Dinleme" bölümlerinin altında yer verilmiştir. Dinleme bölümlerine renkli şeritler ve yönlendirici sembollerle geçiş yapılmaktadır. Dinleme alıştırmalarına tema sonlarında yer verilerek bir standart sağlanmıştır. "Yeni Hitit Yabancılar İ çin Türkçe" setinin temel seviye ders kitabında dinleme alıştırmalarının temalarda veriliş sırasında bir standart bulunmamaktadır. Dinleme alıştırmalarında yönlendirici sembollerden yararlanılmıştır.

$\mathrm{Bu}$ çalışmada, incelenen öğretim setlerinin ders kitaplarında yer alan alıştırmaların temel ve alt becerilere göre dağılımları karşılaştırmalı olarak incelenmiş ve sonuçlara 
ulaşılmıştır (Tablo 1 ve Tablo 2). A1 düzeyindeki ders kitaplarına ilişkin verileri kapsayan Tablo 1, temel ve alt dil becerilerine yönelik alıştırmalar açısından değerlendirilmiştir.

Tablo 1: A1 Düzeyi Ders Kitaplarında Dinleme Alıştırmalarının Diğer Beceri Alanlarına Göre Oranı

\begin{tabular}{lcccccc}
\hline & Dinleme & Konuşma & Okuma & Yazma & Kelime & Dil Bilgisi \\
\hline İstanbul A1 DK & $\% 12$ & $\% 23$ & $\% 18$ & $\% 19$ & $\% 12$ & $\% 16$ \\
Yedi İklim A1 DK & $\% 12$ & $\% 18$ & $\% 24$ & $\% 20$ & $\% 14$ & $\% 12$ \\
Gazi A1 DK & $\% 11$ & $\% 19$ & $\% 25$ & $\% 15$ & $\% 22$ & $\% 8$ \\
Yeni Hitit A1 DK & $\% 14$ & $\% 14$ & $\% 21$ & $\% 17$ & $\% 14$ & $\% 20$ \\
\hline
\end{tabular}

Tablo 1'e göre "İstanbul Yabancilar İçin Türkçe", "Yedi İklim Türkçe” ve "Gazi Yabancılar İçin Türkçe" setlerinin A1 düzeyindeki ders kitaplarında dört temel dil becerisi alanında en az alıştırmaya dinleme becerisi alanında yer verildiği görülmektedir. "Yeni Hitit Yabancılar İçin Türkçe" setinin A1 düzeyindeki ders kitabında ise dinleme ve konuşma becerileri en az alıştırmanın kullanıldığı beceri alanlarıdır. Öğretim setlerinde alt becerilerden kelime ve dil bilgisi alanında kullanılan alıştırmaların oranlarının dinleme alıştırmalarının oranıyla aynı veya fazla olduğu görülmektedir. Diğer bir ifadeyle "İstanbul Yabancılar İçin Türkçe" ve "Yeni Hitit Yabancılar İçin Türkçe" setlerinin A1 düzeyindeki ders kitaplarında dil bilgisi alıştırmaları; "Yedi İklim Türkçe" ve "Gazi Yabancılar İçin Türkçe" setlerinde ise kelime alıştırmalarının oranı dinleme alıştırmalarının oranından daha fazladır. Bu durum dinleme becerisi alanının diğer beceri alanlarının gölgesinde kaldığını göstermektedir.

İncelenen öğretim setlerinin A2 düzeyindeki ders kitaplarında yer alan alıştırmaların temel ve alt dil becerilerine göre dağılımları da tablolaştırılmıştır (bk. Tablo 2).

Tablo 2: A2 Düzeyi Ders Kitaplarında Dinleme Alıştırmalarının Diğer Beceri Alanlarına Göre Oranı

\begin{tabular}{lcccccc}
\hline & Dinleme & Konuşma & Okuma & Yazma & Kelime & Dil Bilgisi \\
\hline İstanbul A2 DK & $\% 12$ & $\% 27$ & $\% 21$ & $\% 12$ & $\% 6$ & $\% 22$ \\
Yedi İklim A2 DK & $\% 15$ & $\% 19$ & $\% 24$ & $\% 19$ & $\% 14$ & $\% 9$ \\
Gazi A2 DK & $\% 11$ & $\% 22$ & $\% 30$ & $\% 11$ & $\% 17$ & $\% 9$ \\
Yeni Hitit A2 DK & $\% 14$ & $\% 13$ & $\% 25$ & $\% 13$ & $\% 14$ & $\% 21$ \\
\hline
\end{tabular}

Tablo 2'ye göre "İstanbul Yabanclar için Türkçe" setinin A2 düzeyindeki ders kitabında yazma ve dinleme, dört temel beceri alanında en az alıştırmanın kullanıldığı beceri alanlarıdır. "Yedi İklim Türkçe" setinin A2 düzeyindeki ders kitabında ise dört temel beceri alanında en az dinleme becerisine yönelik alıştırmalara yer verilmiştir. "Gazi Yabancılar İçin Türkçe" setinin A2 düzeyindeki ders kitabında ise dinleme ve yazma en az alıştırmanın kullanıldığı beceri alanlarıdır. "Yeni Hitit Yabancılar İçin Türkçe" setinin A2 düzeyindeki kitabında ise dinleme alıştırmalarının oranının konuşma ve yazma beceri alanlarında kullanılan alıştırmaların oranından daha yüksek olduğu görülmektedir. Dinleme alıştırmalarının, "İstanbul Yabancılar İçin Türkçe" ve "Yeni Hitit Yabancılar İçin Türkçe" setlerinin A2 düzeyindeki ders kitaplarında alt becerilerden dil bilgisi, "Gazi Yabancilar İçin Türkçe" setinin A2 düzeyindeki ders kitabında ise kelime alıştırmalarının gölgesinde kaldığı görülmektedir.

SEFAD, 2019; (42): 197-212 
A1 ve A2 düzeyindeki ders kitaplarında bulunan dinleme alıştırmalarının oranları birbirleriyle karşılaştırıldığında (Bk. Tablo 1 ve 2), "İstanbul Yabancılar İçin Türkçe”, "Gazi Yabancılar İçin Türkçe" ve "Yeni Hitit Yabancılar İçin Türkçe" ders kitaplarında dinleme alıştırmalarının diğer beceri alanlarına göre oranında bir değişiklik söz konusu değildir. Ancak "Yedi İklim Türkçe" setinin A2 düzeyindeki ders kitabında dinleme alıştırmalarının oranı A1 düzeyindeki ders kitabına göre \%3’lük bir artış göstermiş̧tir. Bu durum, öğretim setinin A2 düzeyinde dinleme becerisine daha fazla önem verildiğini göstermektedir.

Öğretim setlerinin A1 düzeyindeki ders kitaplarında kullanılan dinleme metinlerinin sayısı ve temalara göre dağılımı değerlendirildiğinde, "İstanbul Yabancılar İçin Türkçe" setinin A1 düzeyindeki ders kitabında dinleme metinlerine her üniteye üç, her temaya bir metin gelecek şekilde yer verildiği tespit edilmiştir. Diğer bir ifadeyle A1 düzeyindeki ders kitabında bulunan 18 temada toplam 18 dinleme metnine yer verilmiştir. "Yedi İklim Türkçe" setinin A1 düzeyindeki ders kitabında 33 dinleme metni kullanılmıştır. Ders kitabında yer alan 24 temanın hepsinde en az bir dinleme metnine yer verilmiştir. "Gazi Yabancılar İçin Türkçe" setinin A1 düzeyindeki ders kitabında ise toplam 22 dinleme metnine yer verilmiştir. Ders kitabı, yaklaşık olarak her temada bir dinleme metni olacak şekilde kurgulanmıştır. Sadece birinci ünitenin dördüncü ve üçüncü ünitenin ikinci temasında dinleme metnine yer verilmemiştir. "Yeni Hitit Yabancılar İçin Türkçe" setinin A1 düzeyindeki ders kitabında 30 dinleme metni bulunmaktadır. Kullanılan dinleme metinlerinin temalara göre dengeli bir dağılım göstermediği anlaşılmaktadır.

Bu çalışmada ayrıca, incelenen öğretim setlerinin ders kitaplarında dinleme metinlerinden yararlanılarak hazırlanan alıştırma türleri ve kullanım sıklıkları incelenmiş ve değerlendirilmiştir. A1 düzeyindeki ders kitaplarında dinleme alıştırmalarının türleri ve kullanım sıklıkları Grafik 1'de bir araya getirilmiştir.

Grafik 1: A1 Düzeyindeki Ders Kitaplarında Dinleme Alıştırması Türleri ve Kullanım Sıklıkları

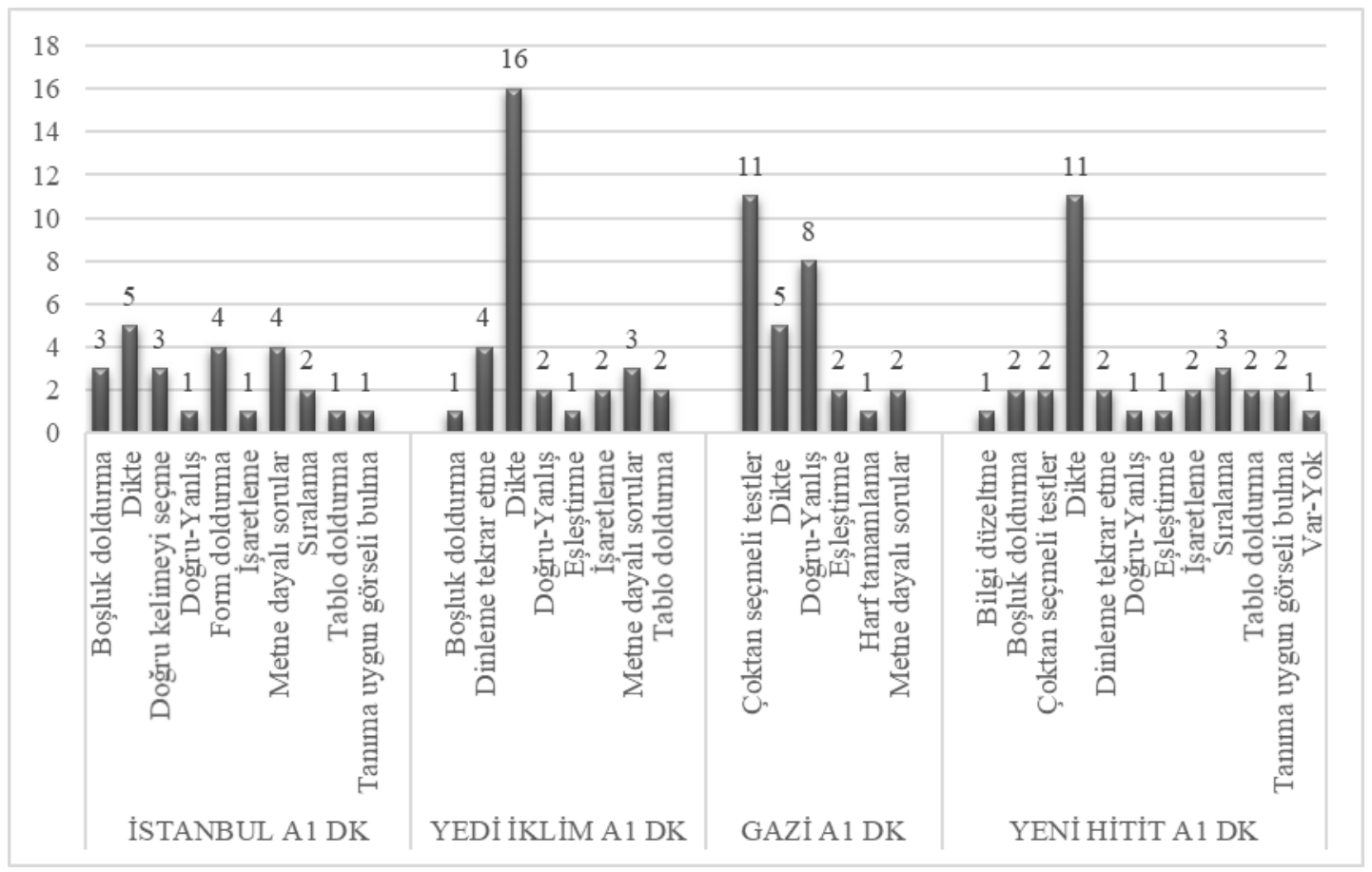


Grafik 1'de görüldüğü gibi "İstanbul Yabancılar İçin Türkçe” setinin A1 düzeyindeki ders kitabında dinleme becerisi alanında 10 alıştırma türü kullanılmıştır. Dikte, form doldurma alıştırmaları ve metne dayalı sorular kullanım sıklığı en yüksek alıştırma türleri arasında yer almaktadır. Bu alıştırmaları, boşluk doldurma ve doğru kelimeyi seçme alıştırmaları izlemektedir. Doğru-yanlış, işaretleme, sıralama, tablo doldurma ve tanıma uygun görseli bulma alıştırmaları kullanım sıklıkları sınırlı alıştırma türleridir. Dinleme becerisi alanında kullanılan alıştırmalardan beş tanesi metinde boş bırakılan kelimelerin dinleme metni doğrultusunda tamamlanması istenilen dikte alıştırmalarıdır. Dinleme metni doğrultusunda hazırlanan dinleme-anlama alıştırmalarının kullanım sıklığının toplamı 19 'dur. Metne dayalı sorular, doğru-yanlış ve boşluk doldurma gibi geleneksel alıştırma türlerinin yanı sıra dinleme metni doğrultusunda sıralama, form ve tablo doldurma alıştırmalarına da yer verilmiştir.

"Yedi İklim Türkçe" setinin A1 düzeyindeki ders kitabında dinleme becerisi alanında sekiz alıştırma türüne yer verilmiştir (Bk. Grafik 1). Dikte alıştırmasının kullanım sıklığı, diğer tüm alıştırma türlerinin kullanım sıklıklarının toplamından daha fazladır. Kullanılan alıştırma türlerinden dört tanesi dinleme tekrar etme alıştırmalarıdır. Dinleme tekrar etme alıştırmaları, dinleme-anlama becerisi değerlendirmekten daha çok öğrencilerin Türkçeye kulak alışkanlığı kazanması ve sesletim becerilerini geliştirmek amacıyla kullanıldığı söylenebilir. Brown'a (2001, s. 255) göre bu tür dinlemelerde öğrenciler sadece duyduklarını tekrar ederler ve duyduklarından anlam üretmezler. Bu nedenle öğrencilerin bu tür dinlemelerdeki tek görevi, duyduklarını bireysel veya toplu olarak sesletim kurallarına uygun olarak tekrar etmektir. Dinleme becerisi alanında kullanılan 16 alıştırma dikte alıştırmalarından oluşmaktadır. Bu alıştırmalarda ise öğrencilerden duydukları kelimeleri metinde boş bırakılan yerlere yazmaları beklenmektedir. Diğer bir ifadeyle bu dikte alıştırmalarında öğrencilerden duydukları sesleri yazılı olarak kodlamaları beklenir. Dinleme-anlamayı değerlendirmeye yönelik kullanılan boşluk doldurma, doğru-yanlış, eşleştirme işaretleme, metne dayalı sorular ve tablo doldurma alıştırmalarının toplam kullanım sıklığı 11'dir. Bu veriler ışığında dinleme becerisi alanında dinleme-anlamaya yönelik alıştırma sayısının sınırlı olduğu söylenebilir.

"Gazi Yabancılar İçin Türkçe" setinin A1 düzeyindeki ders kitabında ise dinleme becerisi alanında altı alıştırma türüne yer verilmiştir. Çoktan seçmeli testler, doğru-yanlış ve dikte alıştırmaları kullanım sıklığı en yüksek alıştırma türleri arasında yer almaktadır. Eşleştirme, harf tamamlama ve metne dayalı sorular kullanım sıklığı sınırlı olan alıştırma türleridir (Bk. Grafik 1). Alıştırma türü sayısı göz önünde bulundurulduğunda dinleme becerisi alanında alıştırma çeşitliliğinin sağlanmadığı görülmektedir. Alıştırma türleri daha detaylı incelendiğinde, alıştırmalardan beş tanesinin dikte alıştırmalarından oluştuğu görülmektedir. Dinleme-anlamayı değerlendirmeye yönelik alıştırma türlerinin kullanım sıklığının toplamı 24'tür. Bu alıştırmalar; çoktan seçmeli testler, metne dayalı sorular, doğruyanlış ve eşleştirme alıştırmalarından oluşmaktadır. Dinleme alıştırmalarında dinlemeanlamaya yönelik yeterince alıştırmaya yer verildiği ancak kullanılan alıştırma türü sayısının sınırlı olduğu anlaşılmaktadır. Dinleme-anlama becerisiyle ilgili alıştırmaların yeniden gözden geçirilmesi gereklidir çünkü daha çok seçme gerektiren çoktan seçmeli testlerin, eşleştirme ve doğru-yanlış alıştırmalarının kullanılması şans başarısından dolayı öğretmenlere ve öğrencilere doğru geri bildirimler vermeyebilir.

SEFAD, 2019; (42): 197-212 
"Yeni Hitit Yabancılar İçin Türkçe" setinin A1 düzeyindeki ders kitabında dinleme becerisi alanında kullanılan alıştırma türü sayısı 12'dir. Alıştırma çeşitliliği açısından dinleme becerisi alanında A1 düzeyindeki ders kitapları arasında en çok alıştırma türünün kullandığ1 kitaptır (Bk. Grafik 1). Fakat alıştırma türlerinin kullanım sıklıklarına bakıldığında, dikte alıştırmalarının kullanım sıklığının diğer alıştırma türlerine oranla çok daha yüksek olduğunu görülmektedir. Sıralama alıştırmaları, dikte alıştırmalarından sonra en yüksek kullanım sıklığına sahip ikinci alıştırma türüdür. Bilgi düzeltme, çoktan seçmeli testler, dinleme tekrar etme, doğru-yanlış, eşleştirme, işaretleme, tablo doldurma, tanıma uygun görseli bulma ve var-yok alıştırmaları kullanım sıklıkları sınırlı olan alıştırma türleri arasında yer almaktadır. Dinleme becerisi alanına dâhil edilmeyen bu alıştırmaların yanı sıra ders kitabının 12, 34, ve 74. sayfalarında dinleme kontrol etme alıştırmalarına yer verilmiştir. $\mathrm{Bu}$ sayfalarda yer alan alıştırmalar, dinleme-anlama becerisini değerlendirmekten ziyade alıştırmanın öğrenciler tarafından doğru yapılıp yapılmadığını kontrol etmek amacıyla kullanılmıştır. Dinleme becerisi alanında kullanılan alıştırmalardan 11'i dikte ve iki tanesi dinleme tekrar etme alıştırmasıdır. Dinleme-anlama becerisine yönelik olarak kullanılan alıştırma türlerinin toplam kullanım sıklığının sayısı $17^{\prime}$ dir. Bu alıştırmalarda çoktan seçmeli testler, doğru-yanlış, boşluk doldurma gibi geleneksel alıştırma türlerinin yanı sıra işaretleme, tablo doldurma, eşleştirme alıştırmalarına da yer verilmiştir ancak bu alıştırma türlerinin kullanım sıklığı sinırlıdır.

Dinleme becerisi alanında kullanılan alıştırma türlerine A1 düzeyindeki tüm ders kitapları açısından bakıldığında, "İstanbul Yabancılar İçin Türkçe", "Yedi İklim Türkçe" ve "Yeni Hitit Yabancılar İçin Türkçe" setlerinin ders kitaplarında dikte alıştırmasının en yüksek kullanım sıklığına sahip alıştırma türü olduğu görülmektedir. Bu durum, dikte alıştırmalarının dinleme becerisine yönelik tasarımlarının incelenmesini gerekli kılmaktadır. Dikte alıştırmalarının bu denli çok kullanılması alıştırmaların tasarlanmasında bazı bölümleri boş bırakılmış metinlerin yazılı hâllerine ders kitaplarında yer verilmesiyle açılanabilir. Benzer şekilde dikte alıştırmalarının "Gazi Yabancılar İçin Türkçe" setinin ders kitabında daha az olması dinleme metinlerinin yazılı hâllerine diğer öğretim setlerine göre daha az yer verilmesiyle açıklanabilir. Bu nedenle de "Gazi Yabancılar İçin Türkçe" setinin ders kitabında çoktan seçmeli testler ve doğru-yanlış alıştırmaları ön plana çıkmaktadır. "Yedi İklim Türkçe" setinin A1 düzeyindeki ders kitabında (Bk. s. 28 ve 34) dinleme metinlerinin yazılı hâllerine de yer verilmiştir. Bu alıştırmalarda öğrenciler alıştırmayı metni dinlemeden sadece okuyarak da yapabilir. Bu iki alıştırmanın bu şekildeki tasarımıla öğrencilerin dinleme-anlama becerilerini geliştirmekten daha çok Türkçenin sesletimine ve öğrencilerin Türkçeye kulak alışkanlığı kazanmasına yönelik bir alıştırma olduğu söylenebilir.

"Yedi İklim Türkçe" setinin ders kitaplarında (Bk. A1 DK, s. 105, 128; A2 DK, s. 43) dikte alıştırmalarının tasarımlarında karşılaşılan diğer bir durum ise metinlerde boş bırakılan yerlere gelecek kelimelerin yazılı hâllerine yer verilmesidir. Bu şekilde tasarlanan dikte alıştırmalarında öğrenciler, metinde boş bırakılan yerlere gelecek kelimeleri boşluk öncesinde ve sonrasında yer alan bilgiler doğrultusunda metnin bağlamından da hareketle diğer bir ifadeyle okuma-anlama yoluyla yazılı hâlleri verilen kelimeler arasından seçerek tahmin edebilir. Aynı şekilde tasarlanan dikte alıştırmalarına "Yeni Hitit Yabancılar İçin Türkçe" setinin A1 düzeyindeki ders kitabında da yer verilmiştir (Bk. s. 12, 34, 56). 
Dikte alıştırmalarında karşılan diğer bir durum ise dinleme metinlerine yönelik hazırlanan alıştırma sayılarıyla ilgilidir. Bazı alıştırmalarda dinleme metni doğrultusunda birden fazla alıştırmaya yer verildiği görülmektedir. Bu alıştırmaların ilkinde öğrencilerden metinde boş bırakılan yerleri dinleme metni doğrultusunda tamamlamaları beklenmektedir. $\mathrm{Bu}$ tür alıştırmalarda öğrenciler, dinleme esnasında metnin genelinden ziyade boş bırakılan yere gelecek kelimeye odaklanır ve boşluklara gelecek kelimeleri yazar. Bu durum, öğrencilerin dinleme metninin genelini anlamasını engelleyebilir. Bu şekilde tasarlanan alıştırmalarda öğrenciler, birinci alıştırma yapıldıktan sonra tamamlanmış bir metin elde eder. Diğer bir ifadeyle öğrenciler, ikinci ve üçüncü alıştırmaları yapmak için dinleme metnine tekrar ihtiyaç duymayacaktır. Öğrenciler, tamamlanmış metinden hareketle ikinci ve üçüncü alıştırmada kendilerinden beklenen görevleri yerine getirecektir. Öğrenciler, ikinci ve üçüncü alıştırmaları tamamlanmış bir metinden hareketle yapacağından bu iki alıştırma türü, dinleme-anlama becerisinin gelişiminden daha çok okuma-anlama becerisinin gelişimine katkı sağlar. Scrivener'de (2005, s. 171) benzer görüşleri dile getirerek dinleme metinlerinin yazılı hâllerinin kullanıldığı alıştırmaların dinleme alıştırmasından okuma alıştırmasına dönüştüğünü ifade eder. Çünkü okuma genellikle birçok öğrenci için dinlemeden daha kolaydır. Bu nedenle öğrenciler bu tür alıştırmaları dinlemeden daha çok yazılı metinden yararlanarak yapma eğilimindedirler. Ur'a $(2012$, s. 114) göre ise bu tür alıştırmaların odak noktası dinlemeden ziyade okuma ve kelimedir. Öğrenciler, alıştırma sürecinde zamanın çoğunu okuma ve kelimeleri yazma ile geçirir. Bu nedenle bu tür alıştırmalarda nitelik sorunu bulunmaktadır. Öğrencilerin dinleme becerilerini geliştirmek için her dinleme için farklı bir alıştırma türü tasarlanarak bu durumun önüne geçilebilir.

Öğretim setlerinin A2 düzeyindeki ders kitaplarında kullanılan dinleme metinlerinin sayıları tespit edilmiş ve aşağıda A1 düzeyi ders kitaplarıyla karşılaştırmalı olarak değerlendirilmiştir: "İstanbul Yabancılar İçin Türkçe" setinin ders kitabında her temada bir dinleme metnine, toplamda 18 dinleme metnine yer verilmiştir. A1 düzeyindeki ders kitabında olduğu gibi bu düzey ders kitabında da temalarda dört temel beceriye göre yapılan bölümlendirme, dinleme metinlerinin temalarda dengeli bir şekilde dağılımında etkili olmuştur. "Yedi İklim Türkçe" setinin A2 düzeyindeki ders kitabında kullanılan dinleme metni sayısı 30'dur. A1 düzeyindeki ders kitabında olduğu gibi her temada en az bir dinleme metnine yer verilmiştir. "Gazi Yabancılar İçin Türkçe" setinin A2 düzeyindeki ders kitabında ise her temada bir, toplamda 20 dinleme metni kullanılmıştır. "Yeni Hitit Yabancılar İçin Türkçe" setinin A2 düzeyindeki ders kitabında ise A1 düzeyindeki ders kitabının aksine her temada en az bir tane olmak üzere toplam 24 dinleme metninden yararlanılmıştır.

Bu kısımda incelenen A2 düzeyindeki ders kitaplarındaki dinleme metinlerine yönelik olarak hazırlanan alıştırma türleri ve kullanım sıklıkları incelenerek değerlendirilmiştir (bk. Grafik 2).

SEFAD, 2019; (42): 197-212 


\section{Grafik 2: A2 Düzeyindeki Ders Kitaplarında Dinleme Becerisi Alanında Kullanılan Alıştırma Türleri ve Kullanım Sıklıkları}

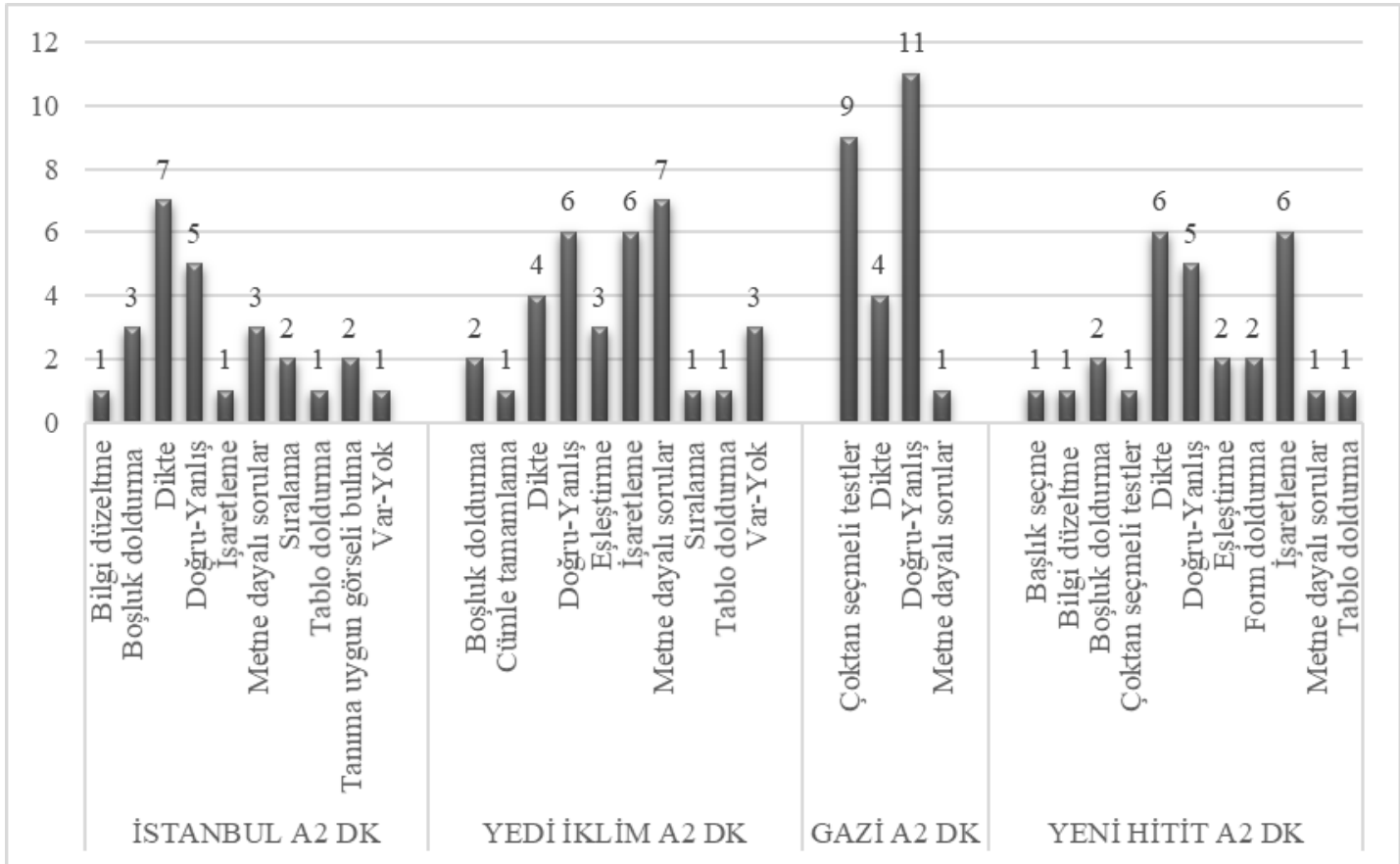

Grafik 2'de görüldügü gibi "İstanbul Yabancılar İçin Türkçe" setinin A2 düzeyindeki ders kitabında dinleme becerisinin geliştirilmesine yönelik 10 alıştırma türü kullanılmıştır. Kullanım sıklığı en yüksek alıştırma türleri; dikte, doğru-yanlış ve metne dayalı sorulardır. Bilgi düzeltme, işaretleme, sıralama, tablo doldurma, tanıma uygun görseli bulma ve varyok alıştırmaları kullanım sıklıkları sınırlı alıştırma türlerindendir. Kullanım sıklığı en yüksek olan dikte alıştırmalarında genellikle diyaloglardan (Bk. s. 11, 15, 19, 30, 63, 74) yararlanılmıştır. Bu durum, öğrencileri gerçek yaşamda karşılaşabilecekleri iletişim durumlarına hazırlaması bakımından yerinde bir uygulama olarak değerlendirilebilir. Dinleme becerisi alanında kullanılan alıştırmalara daha detaylı bakıldığında, alıştırmalardan yedisinin dikte alıştırması olduğu görülmektedir. Dinleme-anlama alıştırmalarının sayısı 17 'dir. Bu bağlamda; doğru-yanlış alıştırmaları, boşluk doldurma ve metne dayalı sorular gibi geleneksel alıştırma türlerinin yanı sıra sıralama, tablo doldurma, tanıma uygun görseli seçme ve işaretleme gibi bir görevle ilişkilendirilmiş alıştırma türlerine de yer verilmiştir.

"Yedi İklim Türkçe" setinin A2 düzeyindeki ders kitabında dinleme becerisi alanında 10 alıştırma türü kullanılmıştır. Bu alıştırma türlerinden metne dayalı sorular, doğru-yanlış ve işaretleme alıştırmaları kullanım sıklığı en yüksek alıştırma türleridir. Bu alıştırma türlerini dikte, eşleştirme ve var-yok alıştırmaları izlemektedir. Cümle tamamlama, sıralama, şarkı söyleme ve tablo doldurma alıştırmaları kullanım sıklığı sınırlı olan alıştırma türleridir (Bk. Grafik 2). Kullanılan dikte alıştırmalarının üçünde kelime düzeyinden cümle düzeyine geçiş yapılmıştır. Dinleme-anlama alıştırmalarının toplam kullanım sıklığı $29^{\prime}$ dur. Bu bağlamda; metne dayalı sorular, cevap verme, doğru-yanlış, var-yok vb. gibi geleneksel alıştırma türlerinin yanı sıra işaretleme, tablo doldurma, sıralama gibi alıştırmalara da yer verilmiştir. 
"Gazi Yabancılar İçin Türkçe" setinin A2 düzeyindeki ders kitabında dinleme becerisi alanında sadece dört alıştırma türünden yararlanılmıştır. Doğru-yanlış alıştırması ve çoktan seçmeli testler kullanım sıklığı en yüksek alıştırma türleridir. Dikte alıştırmaları dört kez kullanılırken metne dayalı sorular bir kez kullanılmıştır (Bk. Grafik 2). Alıştırma türlerinin kullanım sıklığına bakıldığında, dinleme alıştırmalarında alıştırma çeşitliliğginin sağlanmadığı ve üç alıştırma türüne bağlı kalındığı görülmektedir. Dinleme becerisi alanında kullanılan alıştırmaların dört tanesi dikte, 21 tanesi dinleme-anlama alıştırmalarından oluşmaktadır.

"Yeni Hitit Yabancılar İçin Türkçe" setinin A2 düzeyindeki ders kitabında dinleme becerisi alanında ise 11 alıştırma türü kullanılmıştır. Bu alıştırma türlerinden dikte, işaretleme ve doğru yanlış alıştırmaları kullanım sıklığı en yüksek alıştırma türleri arasında yer almaktadır. Başlık seçme, bilgi düzeltme, çoktan seçmeli testler, eşleştirme, form doldurma, metne dayalı sorular ve tablo doldurma alıştırmaları kullanımı sınırlı olan alıştırma türleridir. Dinleme-anlama alıştırmalarında metne dayalı sorular, doğru-yanlış alıştırmaları ve çoktan seçmeli testlerin yanı sıra; işaretleme, tablo doldurma, eşleştirme gibi alıştırma türlerine de yer verilmiştir. Dinleme becerisi alanında kullanılan alıştırmaların altı tanesi dikte, 22 tanesi dinleme-anlama alıştırmalarından oluşmaktadır.

A1 ve A2 düzeyindeki ders kitapları dinleme becerisine yönelik alıştırma türü sayısı açısından karşılaştırmalı olarak değerlendirildiğinde (Bk. Grafik 1 ve Grafik 2), "İstanbul Yabancılar İçin Türkçe" setinde alıştırma türü sayısının (10) aynı kaldığı, "Yedi İklim Türkçe" setinin A2 düzeyindeki ders kitabında kullanılan alıştırma türü sayısının (10) artış gösterdiği görülmektedir. Ancak "Gazi Yabancılar İçin Türkçe" setinin A2 düzeyindeki ders kitabında kullanılan alıştırma türü sayısının (4) A1 düzeyindeki ders kitabına göre düştüğü (6) ve "Yeni Hitit Yabancılar İçin Türkçe" setinin A2 düzeyindeki ders kitabındaki alıştırma türü sayısının (11) A1 düzeyindekine (12) yakın olduğu tespit edilmiştir.

Öğretim setlerinin temel seviyedeki ders kitaplarında dinleme-anlama alıştırmalarında ağırlıklı olarak çoktan seçmeli test, doğru-yanlış, metne dayalı sorular gibi geleneksel alıştırma türlerine yer verildiği görülmektedir. Dinleme metnine göre form, tablo doldurma ve çizim gibi bilgi aktarımına dayalı alıştırma türlerinin kullanım sıklıkları artırılmalıdır. Field (2002, s. 244), bu tür alıştırmaların öğrencilerin dinleme-anlama becerilerini kontrol etmek için daha güvenilir olduğunu belirtmektedir. Dinleme çalışmalarındaki temel zorluk diğer beceriler olmaksızın öğrencilerin ne kadar anladığını tespit etmektedir. Çünkü öğrencilerin dinleme metnine göre hazırlanan doğru-yanlış, varyok, çoktan seçmeli test, metne dayalı sorular gibi alıştırma türlerinde bir soruya yanlış cevap vermesinin nedeni soruyu okuyup anlayamamasından kaynaklanabilir. Benzer şekilde metne dayalı bir soruya yanlış cevap vermesi de cevabı doğru şekilde yazamaması olabilir. Bu nedenle özellikle temel düzeyde okuma ve yazma becerisi kullanımının en az seviyede olduğu bir görevle ilişkilendirilen alıştırmalar, dinleme-anlama becerilerinin tespit edilmesinde daha kesin sonuçlar verebilir. 


\section{SONUÇ}

Bu çalışmada, "İstanbul Yabancılar İçin Türkçe", "Yedi İklim Türkçe", "Gazi Yabancılar İçin Türkçe" ve "Yeni Hitit Yabancılar İçin Türkçe" setlerinin temel seviye (A1A2) ders kitapları dinleme becerisine yönelik alıştırmalar açısından incelenmiş ve aşağıda belirtilen sonuçlara ulaşılmıştır:

"İstanbul Yabancılar İçin Türkçe" ve "Gazi Yabancılar İçin Türkçe" öğretim setlerinin temel seviye ders kitaplarında beceriye dayalı standart bir izlence takip edilmiştir. "Yedi İklim Türkçe" ve "Yeni Hitit Yabancılar İçin Türkçe" setlerinde ise dinleme alıştırmalarının temalar içinde belirli bir yeri olmadığı anlaşılmıştır. Beceriye dayalı izlencelerin kullanıldığı öğretim setlerinin ders kitaplarında, dinleme alıştırmaları temalara göre daha dengeli bir dağılım göstermektedir.

Temel seviye ders kitaplarında dinleme becerisine yönelik alıştırmalar diğer becerilere yönelik alıştırmalarla sayıca karşılaştıııldığında, dinleme becerisine yönelik olanların arka planda kaldığı anlaşılmıştır. Bu durum, öğretim setlerinde dinleme metinlerinin ve dinleme becerisine yönelik alıştırma sayısının artırılması gerektiğini göstermektedir. Çalışmanın bu bulgusu Yavuz (2016) "Gazi Yabancılar İçin Türkçe" setinde dinleme alıştırmalarının sayısının diğer beceri alanlarında yer alan alıştırmalara göre daha az olduğu bulgusuyla benzerlik göstermektedir. Benzer şekilde Tabak ve Göçer'in (2017) yabancı dil olarak Türkçe öğretimi kitaplarında dinleme alıştırmalarının yeterli olmadığı ve diğer becerilerin gölgesinde kaldığı bulgusu çalışmanın sonuçlarını destekler niteliktedir.

İncelenen ders kitaplarının dinleme becerisine yönelik alıştırma türleri incelendiğinde "İstanbul Yabancılar İçin Türkçe", "Yedi İklim Türkçe" ve "Yeni Hitit Yabancılar İçin Türkçe" setlerinde farklı alıştırma türlerinin kullanılarak çeşitlilik sağlandığı görülmüştür. Ancak özellikle "Yedi İklim Türkçe" ve Yeni Hitit Yabancılar İçin Türkçe öğretim setlerinin A1 düzeyindeki ders kitaplarında dinleme alıştırmaların çoğunluğunun dikte alıştırmalarında oluştuğu sonucuna ulaşılmıştır. Çalışmanın bu bulgusu Eken'in (2011) "Yeni Hitit Yabancılar İçin Türkçe" ders kitabında dinleme alıştırmalarına yönelik bulgusuyla benzerlik göstermektedir. Ders kitaplarında kullanılan alıştırma türü sayısı kadar dikkat edilmesi gereken diğer bir nokta da alıştırma türlerinin kullanım sıklıklarıdır. $\mathrm{Bu}$ nedenle her iki öğretim setinin A1 düzeyindeki ders kitaplarında dinleme-anlamaya yönelik alıştırma türlerinin kullanım sıklığının yeterli olmadığı sonucuna ulaşılmıştır. Bu durum, her iki öğretim setinin A1 düzeyindeki ders kitaplarında dinleme-anlamaya yönelik farklı alıştırma türlerinin artırılması gerektiğini göstermektedir. "Yedi İklim Türkçe" ve "Yeni Hitit Yabancılar İçin Türkçe" setlerinde dinleme-anlamaya yönelik kullanılan dikte alıştırmalarıyla ilgili vurgulanması gereken bir başka nokta ise boşluklara getirilecek kelimelerin yazılı hâllerine yer verilmemesi ve bu şekilde dinleme eğitiminin daha işlevsel hâle getirilebileceğidir.

"Gazi Yabancılar İçin Türkçe" setinin temel düzey ders kitaplarında dinleme becerisine yönelik alıştırma türü sayısının oldukça sınırlı olduğu tespit edilmiştir. Alıştırmalar; çoktan seçmeli test, doğru-yanlış ve dikte alıştırmaları olmak üzere üç alıştırma türü ile sınırlandırılmıştır. Çalışmanın bu bulgusu Tabak ve Göçer'in (2017) “Gazi Yabancılar İçin Türkçe" öğretim setinde dinleme alıştırmalarına yönelik yaptığı çalışma sonuçlarıyla benzerlik göstermektedir. Dinleme alıştırmalarının tek düze kalmasına neden olan bu durum, kullanılan alıştırma türlerinin zenginleştirilmesi gerektiğini göstermektedir. 
Dinleme becerisi alanında en çok alıştırma türüne "Yeni Hitit Yabancılar İçin Türkçe" setinde yer verilmiştir. A1 ve A2 düzeyindeki ders kitabında kullanılan alıştırma türü sayısı alıştırmaların çeşitliliğine bir kanıttır ancak yine de A1 düzeyindeki ders kitabında dinlemeanlamaya yönelik alıştırma türlerinin kullanım sıklığının artırılması gerekmektedir.

Bu çalışma, yabancı dil olarak Türkçe öğretimi için hazırlanan ders kitaplarında temel ve alt dil becerilerine yönelik alıştırmaların dağılımlarının ne denli önemli olduğunu göstermiştir. Temel dil becerilerinden dinleme becerisinin temel düzeyden başlanarak edindirilmesi ve ileri ki seviyelerde geliştirilmesi için alıştırmaların sayısının, türlerinin artırılması ve zenginleştirilmesi gerekmektedir.

Günümüz eğitim teknolojisi zenginliğinden de yararlanılarak öğrencileri sadece sınıfta değil sınıf dışında da çeşitli dinleme metinleri ve alıştırmalarla buluşturmak yararlı olacak ve öğrencilerin dinleme-anlama becerilerinin gelişmesine katkı sağlayacaktır.

\section{SUMMARY}

Listening is the most challenging of all the skills in foreign language teaching because there are many difficulties students may face in understanding a talk, lecture or conversation in a second language. Textbooks play an important role in overcoming these difficulties. The target behaviors determined in the listening skill area in the textbooks are acquired by students through exercises. Therefore, it is important to offer a sufficient number of different exercise types for listening skill area in the textbooks prepared for teaching Turkish as a foreign language. Another important point is to provide diversity and qualification in the exercise types used in the listening skill area.

The aim of this study is to determine the proportions of the exercises used in the listening skill relative to other skills, the types of exercises and the frequency of their use in the basic level (A1-A2) textbooks of the four teaching sets commonly used in teaching Turkish as a foreign language. Data were gathered through document analysis from the basic level (A1-A2) of the teaching sets of "Istanbul Turkish for Foreigners", "Yedi İklim Turkish", "Gazi Turkish for Foreigners", "Yeni Hitit Turkish for Foreigners" textbooks and evaluated by inductive content analysis.

The findings of this study clearly show that the least number of exercises were included in the listening skill area in the four basic skills. The number of listening exercises remained insignificiant in comparison to the number of grammar exercises in "Istanbul Turkish for Foreigners" and "Yeni Hitit Turkish for Foreigners" and of vocabulary exercises in "Gazi Turkish for Foreigners". In other words, teaching knowledge took precedence over the teaching skill in these teaching sets.

It was found that the number of types of exercises for listening skills in the basic level textbooks of "Gazi Turkish for Foreigners" is quite limited. Exercises are limited to these three types: multiple-choice test, true-false and dictation exercises. Although different types of exercises are used in A1 level textbooks of "Yedi İklim Turkish" and "Yeni Hitit Turkish for Foreigners", the frequency of exercises aimed at developing listening comprehension skills is limited.

In the basic level (A1-A2) textbooks of the four teaching sets, mostly traditional types of exercises such as multiple-choice test, true-false, text-based questions were used for

SEFAD, 2019; (42): 197-212 
listening comprehension. Exercise types based on information transfer such as form, table filling and drawing should be given more space.

This study shows how important the distribution of exercises according to basic and sub language skills in textbooks prepared in Turkish as a foreign language teaching is. Listening-understanding skill, which is one of the four basic language skills, should be acquired and improved on starting from the basic level and the number and types of exercises should be increased and enriched. 


\section{KAYNAKÇA}

Brown, H. D. (2001). Teaching by Principles, An Interactive Approach to Language Pedagogy (2. bs.). White Plains: Longman.

Cavkaytar, S. (2009). Dengeli Okuma Yazma Yaklaşımının Türkçe Öğretiminde Uygulanması: Illköğretim 5. Sinıfta Bir Eylem Araştırması. Basılmamış Doktora Tezi, Anadolu Üniversitesi, Eskişehir.

Demirel, Ö. (2016). Yabancı Dil Öğretimi (9. bs.). Ankara: Pegem Akademi.

Eken Tuzcu, D. (2011). Yabancı Dil Olarak Türkçe ve İngilizce Öğretiminde Temel Düzey DinlemeAnlama Etkinliklerinin Karşılaştırılması. Basılmamış Yüksek Lisans Tezi, İstanbul Üniversitesi, İstanbul.

Field, J. (2002). The Changing Face of Listening. J. C. Richards ve W. A. Renandya (Ed.), Methodology in Language Teaching An Anthology of Current Practice içinde (1. bs., ss. 242247). New York: Cambridge University Press.

Gürbüz, S. ve Şahin, F. (2017). Sosyal Bilimlerde Araştırma Yöntemleri (4. bs.). Ankara: Seçkin.

Scrivener, J. (2005). Learning Teaching. A Guidebook for English Language Teachers (2. bs.). Oxford: Macmillan.

Şimşek, R. (2016). Yabanclara Türkçe Öğretiminde Kullanılan Ders Kitaplarının Temel Dil Becerileri Bağlamında Karşılaştırmalı Olarak İncelenmesi. Basılmamış Yüksek Lisans Tezi, Nevşehir Hacı Bektaş Veli Üniversitesi, Nevşehir.

Tabak, G. ve Göçer, A. (2017). Türkçenin Yabancı Dil Olarak Öğretiminde A1-C1 Düzey Dinleme Etkinliklerinin İncelenmesi. Cumhuriyet Uluslararası Eğitim Dergisi, 6(3), 400411.

Tüm, G. (2016). Yabancılara Türkçe Ders Kitaplarındaki Dinleme Etkinliklerinin Avrupa Ortak Başvuru Metnine Uygunluğu Üzerine Bir Çalışma. International Journal of LanguagesEducation and Teaching Education and Teaching, (2), 125-142.

Ur, P. (2012). A Course in English Language Teaching (2. bs.). Cambridge: Cambridge University Press.

Yavuz, G. (2016). Gazi TÖMER Yabancılar İçin Türkçe Öğretim Seti Dinleme Etkinliklerinin İncelenmesi. Basılmamış Yüksek Lisans Tezi, Gaziosmanpaşa Üniversitesi, Tokat.

Yıldırım, A. ve Şimşek, H. (2016). Sosyal Bilimlerde Nitel Araştırma Yöntemleri (10. gen. bs.). Ankara: Seçkin.

Yılmaz, F. ve Babacan, G. (2015). Dinleme Eğitimi ve Dinleme Becerisini Geliştirmeye Yönelik Etkinlikler. International Journal of Languages' Education and Teaching, 905-923. 


\section{EK: İncelenen Ders Kitapları}

Bölükbaş, F. ve Yılmaz, Y. M. (Ed.). (2017). İstanbul Yabancılar İçin Türkçe Ders Kitabı A1. İstanbul Üniversitesi DİLMER Yayını (20. bs.). İstanbul: Kültür Sanat Basımevi.

Bölükbaş, F. ve Yılmaz, Y. M. (Ed.). (2017). İstanbul Yabancılar İçin Türkçe Ders Kitabı A1. İstanbul Üniversitesi DILLMER Yayını (14. bs.). İstanbul: Kültür Sanat Basımevi.

Barın, E., Çobanoğlu, Ş., Ateş, Ş., Balcı, M. ve Özdemir, C. (Ed.). (2016). Yedi İklim Türkçe A1 Ders Kitabı. Yunus Emre Enstitüsü Yayını (3. bs.). Ankara: Başak Matbaacılık.

Barın, E., Çobanoğlu, Ş., Ateş, Ş., Balcı, M. ve Özdemir, C. (Ed.). (2016). Yedi İklim Türkçe A2 Ders Kitabı. Yunus Emre Enstitüsü Yayını (3. bs.). Ankara: Türkiye Diyanet Vakfı Yayın Matbaacilık.

Kurt, M. ve Temur, N. (Ed.). (2015). Yabancılar İçin Türkçe A1 Temel Düzey Ders Kitabı. Gazi Üniversitesi TÖMER Yayını (7. bs.). Ankara: Salmat Basım Yayıncılık.

Kurt, M. ve Temur, N. (Ed.). (2015). Yabancılar İçin Türkçe A2 Temel Düzey Ders Kitabı. Gazi Üniversitesi TÖMER Yayını (7. bs.). Ankara: Salmat Basım Yayıncılık.

Uzun, N. E. (Ed.). (2016). Yeni Hitit Temel Seviye A1-A2. Ankara Üniversitesi TÖMER Yayını. Ankara: Ankara Üniversitesi Basımevi. 